\title{
AUDIOMETRIC WEBER AND RINNE TESTS AS COMPARED TO PURE-TONE THRESHOLDS
}

\author{
THOMPSON, ALISON K., B.A. (SP. \& H. TH.) (WITWATERSRAND) \\ Speech Therapy Department, General Hospital, \\ Johannesburg
}

\begin{abstract}
SUMMARY
Results of the audiometric Weber and Rinne tests were compared to pure tone thresholds in 185 Bantu patients. The frequency of $1000 \mathrm{~Hz}$ was selected as being most suitable for Weber and Rinne testing. The Weber was found to be of limited diagnostic value even with unilateral conductive losses whilst the Rinne displays a fair degree of efficiency and is of value as a routine supplement to audiometric threshold tests.
\end{abstract}

\section{OPSOMMING}

Resultate van die oudiometriese Weber en Rinne toetse is met suiwertoon drempels vergelyk. 185-Bantoe pasiënte is as proefpersone gebruik. Die frekwensie van $1000 \mathrm{hz}$ is as die geskikste vir die Weber en Rinne toetse gereken. Die Weber is, selfs met eensydige geleidings verlies, van beperk te diagnostiese waarde gevind, terwyl die Rinne 'n redelike graad van doeltreffendheid getoon het en aanvullend by die oudiometriese drempel toet se gebruik kan word.

At the hearing clinic at Baragwanath Hospital, Johannesburg, routine audiometric Weber and Rinne tests were fairly frequently found to be inconsistent with pure tone thresholds. In the present study, a large number of pure tone audiograms were compared with audiometric Rinne and Weber results.

In recent years, very little has appeared in the literature concerning the Weber and Rinne tests. That which has appeared deals almost exclusively with testing by means of tuning forks. Most authors stress the need to include the Weber and Rinne in a battery of tuning fork tests including the Schwabach and Gellé tests. ${ }^{1 \cdot 3,6}, 8,11,12$ Reliability of these tests has been questioned by these workers but they are nevertheless considered to be useful in supplementing audiometric results.

Testing by means of the audiometric bone vibrator has certain advantages over testing by means of tuning forks. ${ }^{2,8,13}$ The bone vibrator maintains its intensity output at any desired level, whereas the tuning fork fades rapidly in intensity, especially in the high frequencies. ${ }^{11}$ In addition, the bone vibrator permits a standard presentation which is independent of the ear of the operator. ${ }^{5,13}$

\section{MATERIALS AND METHODS}

Hearing assessments of 185 South African Bantu of both sexes with an age range of 12 to 75 years were analysed. These were taken randomly from the 
records of patients tested at the hearing clinic over an 18 month period. A Maico MA-10 audiometer calibrated to I.S.O. 1964 hearing threshold levels was used for testing. The test room was not ideally soundproofed despite the fact that it was lined with acoustic board.

Conventional pure tone air- and bone-conduction audiograms were obtained for each patient. Both the Weber and Rinne were tested at an intensity of 15 $\mathrm{dB}$ above the patient's threshold of audibility (vibrator placed on the midline of the forehead). ${ }^{8}$ This is sufficient intensity for clear audibility yet it minimises cross-hearing by being close to the patient's threshold.

Test ing by the Weber and Rinne methods at several frequencies was considered laborious and unnecessary. A test frequency of $1000 \mathrm{~Hz}$ was invest $\mathrm{i}$ gated and finally utilised for the following reasons:

1) An increase in the force of vibrator application results in an improved. threshold. The greatest change in intensity due to differential force occurs at $250 \mathrm{~Hz}$ whilst only slight changes occur at $1000 \mathrm{~Hz}, 4,9$

2) Middle ear lesions influence the vibratory mechanism of the inner ear thereby providing an artefact of poorer bone conduction thresholds. ${ }^{1}$ Although this phenomenon is not yet fully explained, it appears to occur most frequently in the lower frequencies where the conductive loss is generally at a maxinum. ${ }^{7}$

3) Witli lower frequencies the Rinne is more likely to be negative in normal ears whereas the reverse is true with higher frequencies. ${ }^{11}$ The centrally situated $1000 \mathrm{~Hz}$ is hypothetically more reliable.

4) With frequencies below $1000 \mathrm{~Hz}$ there is a possibility of confusion between the tactile sensation and hearing. This is enhanced with presentation at higher intensities.

5) A frequency of $1000 \mathrm{~Hz}$ is situated at the centre of the critical frequency range, and is likely to reflect most successfully both conductive and sensorineural losses.

6) Tones below $1000 \mathrm{~Hz}$ appear to be most affected by ambient noise. This assumes importance when the test environment is not completely soundproof.

In Rinne testing a conductive loss of $15 \mathrm{~dB}$ reverses the response at $\pm 500 \mathrm{~Hz}$ (i.e. B-C better than A-C), whilst a $20 \mathrm{~dB}$ loss is required to reverse the response at $1000 \mathrm{~Hz} .{ }^{10}$ The test is thus slightly less sensitive at $1000 \mathrm{~Hz}$. However, as the levels of $0 \mathrm{~dB}$ to $20 \mathrm{~dB}$ are considered to constitute the normal hearing range, the required sensitivity is present.

The audiograms were classified by two audiologists into 11 broad catégories of bilateral hearing characteristics. (Refer to categories listed in Tables $\mathbf{l}$ and II). Conventional interpretation criteria were applied. Those classified differently were discarded.

Two assessments were made regarding the Weber and Rinne results in relation ' to each audiogram:

1) Correct/error according to the characteristic of air-and bone-conduction thresholds at $1000 \mathrm{~Hz}$ only. 
2) Correct/error as to whether the results reflected the total loss characteristics of the given ear $/ \mathrm{s}$ as indicated by thresholds over the range of 250 $8000 \mathrm{~Hz}$.

Criteria for assessment of the Weber test were based on research by Groen. ${ }^{1,3,7}$ Lateralisation appears to involve the recognition of interaüral phase and time as well as intensity differences. Lateralisation occurs in normal ears owing to:

a) One stronger vibrating cochlea, as a result of better sound conduction to that cochlea.

b) A phase difference between the two sound waves entering the cochleae, the bone conducted tone being lateralised in the cochlea with the leading phase.

In nornal ears (owing to slight anatomical differences) phase advances may overcome relative amplitude deficiencies of up to $6 \mathrm{~dB}$. Owing to this phenomenon, a $5 \mathrm{~dB}$ amplitude difference between bilateral ear thresholds was accepted in the obtaining of a midline response. Lateralisation was expected at differences of $10 \mathrm{~dB}$ or above.

Criteria for assessment of the Rinne test were based on the findings of Sheehy. ${ }^{10}$ At $1000 \mathrm{~Hz}$ an air-bone gap of less than $20 \mathrm{~dB}$ is accompanied by a Rinne positive response. A Rinne negative response occurs with a gap of $20 \mathrm{~dB}$ or more. Theoretically, there is a point around $20 \mathrm{~dB}$ where both $\mathrm{A}-\mathrm{C}$ and B-C appear equally loud. This "indifferent" Rinne was accept ed as correct with an air-bone gap of $20 \mathrm{~dB}$ only.

\section{RESULTS AND DISCUSSION}

Tables I and II summarise the results in the present study. These were analysed statistically using the Cochrans Q test, binomial test and Poisson test. The results at $1000 \mathrm{~Hz}$ only were compared with the total results for each audiogram in order to determine whether the result at $1000 \mathrm{~Hz}$ only was able to reflect the total loss characteristics of the ear $/ \mathrm{s}$. For both the Weber and Rinne tests there was no significant difference between the total results and the results at $1000 \mathrm{~Hz}$ only $(\mathrm{p}<0,05)$. Testing at $1000 \mathrm{~Hz}$ is therefore suitable as a test frequency although, clearly, it cannot ind icate precipitous high or low frequency loss.

The Weber test is generally far less efficient than the Rinne test. This is demonstrated by the finding that in the Weber test, three loss combinations demonstrated highly significant response errors $(p<0,005)$. These were bilateral normal $(A)$, bilateral equal sensori-neural $(E)$ and bilateral conductive ears $(C)$. These findings are interesting in that combinations $A(56,3 \%$ error*) and $\mathrm{E}(55,5 \%$ error) have bilaterally equal cochlear reserve and the Weber response should therefore be central. That this does not occur indicates that

* All percentages apply to results at $1000 \mathrm{~Hz}$ only. 


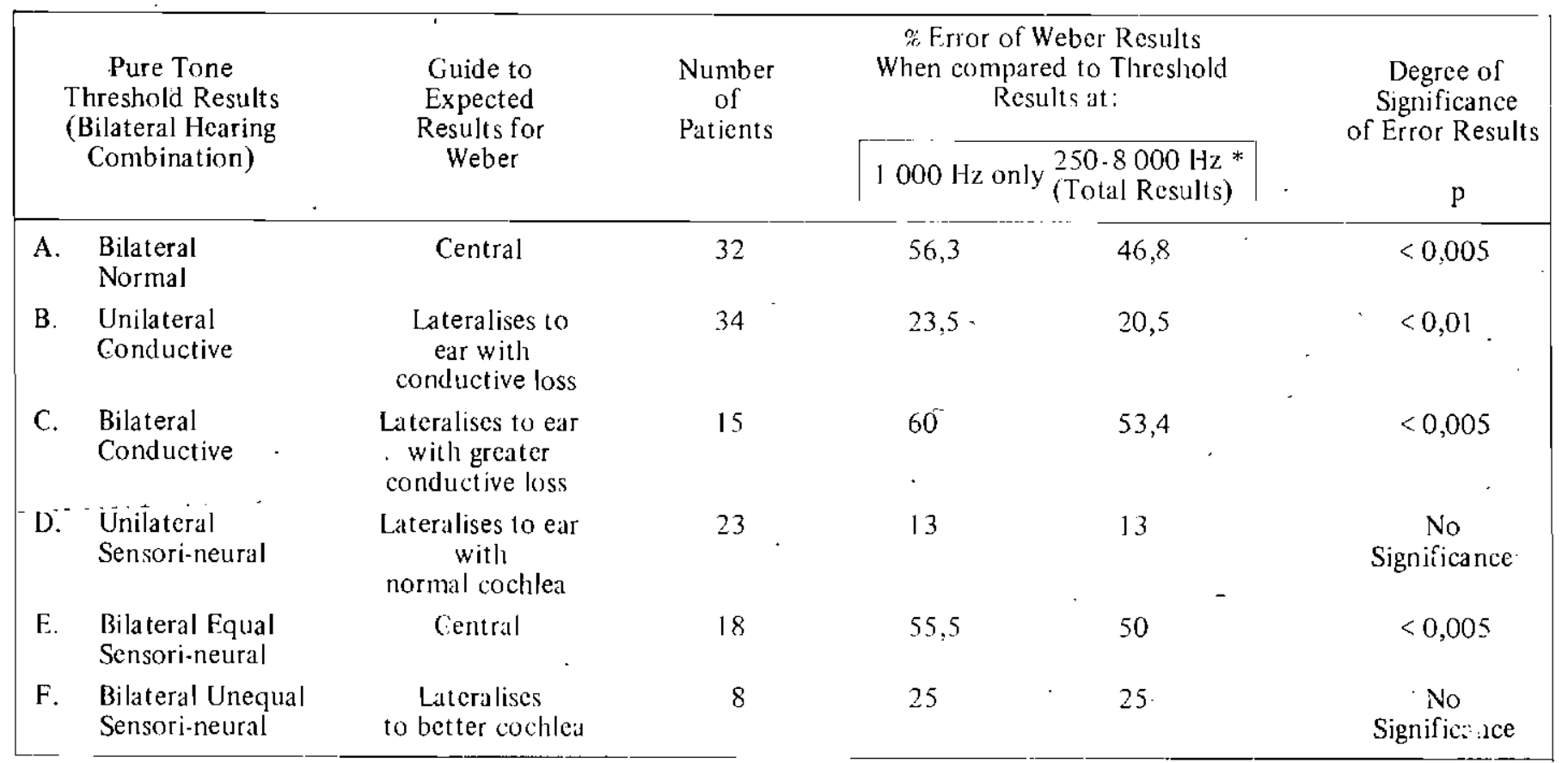

*. Weber result compared to thresholds over this range to assess agreement with total loss characteristics of the ears.

TABLE I. Comparison of the agreement between the Weber and pure tone threshold results. 


\begin{tabular}{|c|c|c|c|c|c|}
\hline \multirow{2}{*}{ 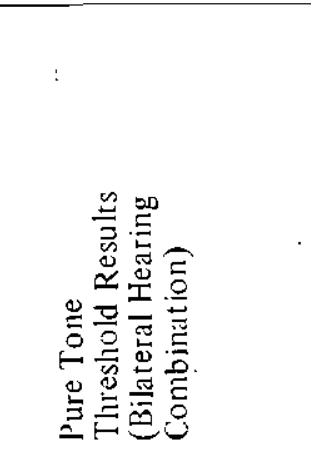 } & . & & 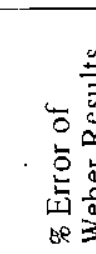 & 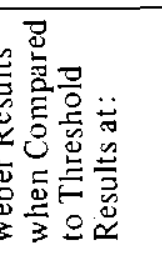 & \multirow{2}{*}{ · } \\
\hline & 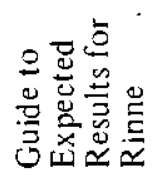 & 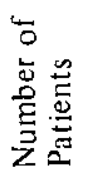 & $\begin{array}{l}\text { ํㅗ. } \\
8 \\
\frac{8}{\delta}\end{array}$ & 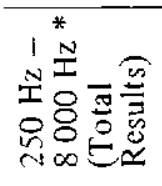 & \\
\hline $\begin{array}{l}\text { A. Bilateral } \\
\text { Normal }\end{array}$ & Both +ve & 32 & 3,1 & 6,3 & No Significance \\
\hline $\begin{array}{l}\text { B. One Normal } \\
\text { One conductive }\end{array}$ & $\begin{array}{l}+\mathrm{ve} \\
--\mathrm{ve}\end{array}$ & 34 & $\begin{array}{r}11,8 \\
8,8\end{array}$ & $\begin{array}{l}11,8 \\
17,7\end{array}$ & $\begin{array}{l}\text { No Significance } \\
\text { No Significance }\end{array}$ \\
\hline $\begin{array}{l}\text { C. Bilateral } \\
\text { Conductive }\end{array}$ & Both -ve & 15 & 10 & 10 & No Significance \\
\hline $\begin{array}{l}\text { D. One Normal } \\
\text { One Sensori- } \\
\text { neural }\end{array}$ & $\begin{array}{c}\text { +ve } \\
\text { False -ve }\end{array}$ & 23 & $\begin{array}{l}0 \\
8,7\end{array}$ & $\begin{array}{l}0 \\
8,7\end{array}$ & $\begin{array}{l}\text { No Significance } \\
\text { No Significance }\end{array}$ \\
\hline $\begin{array}{l}\text { E. Bilateral Equal } \\
\text { Sensori-neural }\end{array}$ & Both +ve & 18 & 11,1 & 11,1 & $<0,05$ \\
\hline $\begin{array}{l}\text { F. Bilateral Unequal } \\
\text { Sensori-neural }\end{array}$ & $\begin{array}{l}\text { One +ve } \\
\text { and one } \\
\text { False -. ve }\end{array}$ & 8 & 6,3 & 6,3 & No Significance \\
\hline $\begin{array}{l}\text { G. One Normal } \\
\text { One Mixed }\end{array}$ & $\begin{array}{l}\text { +ve } \\
\text { False -ve }\end{array}$ & 20 & $\begin{array}{r}0 \\
30\end{array}$ & $\begin{array}{r}0 \\
25\end{array}$ & $\begin{array}{c}\text { No Significance } \\
<0,05\end{array}$ \\
\hline $\begin{array}{c}\text { H. One Sensori- } \\
\text { neural } \\
\text { One Mixed }\end{array}$ & & 14 & $\begin{array}{l}35,7 \\
21,4\end{array}$ & $\begin{array}{l}35,7 \\
28,6\end{array}$ & $\begin{array}{l}<0,05 \\
<0,05\end{array}$ \\
\hline $\begin{array}{l}\text { 1. One Sensori- } \\
\text { neural } \\
\text { One Conductive }\end{array}$ & $\begin{array}{c}\text { False -ve } \\
\text {-ve }\end{array}$ & 5 & $\begin{array}{l}20 \\
40\end{array}$ & $\begin{array}{l}20 \\
40\end{array}$ & $\begin{array}{l}\text { No Significance } \\
\text { No Significance }\end{array}$ \\
\hline $\begin{array}{l}\text { J. One Conductive } \\
\text { One Mixed }\end{array}$ & $\begin{array}{c}-v e \\
\text { False -ve }\end{array}$ & 6 & $\begin{array}{c}16,7 \\
0\end{array}$ & $\begin{array}{l}16,7 \\
16,7\end{array}$ & $\begin{array}{l}\text { No Significance } \\
\text { No Significance }\end{array}$ \\
\hline $\begin{array}{l}\text { K. Bilateral } \\
\text { Mixed }\end{array}$ & & 10 & 10 & 10 & $<0,05$ \\
\hline
\end{tabular}

* Rinne result compared to thresholds over this range to assess agreement with total loss characterjstics of ear.

TABLE II. Comparison of the agreement between the Rinne and pure tone threshold results. 
either the patient resists believing he can hear the tone centrally (in spite of being prepared for this possibility during testing) or that the test is more sensitive than desired in that a slight deficit in the conductive mechanism results in lateralisation in normal ears. No definite trend was found as to the ear selected for response; neither the ear where pathology or loss was judged present nor the better functioning ear was selected.

In the bilateral conductive combination (60\% error) similar factors are present in that frequently the degree of loss is practically equal in both ears. $\Lambda$ central Weber was expected, but seldom occurred.

Nlthough the Weber is considered to be primarily a test for determining presence of unilateral conductive loss, results did not support this very well $(23,5 \%$ error; significant at $\mathrm{p}<0,01)$.

The Weber appears to be reliable in two combinations only i.e. bilateral un. equal sensori-neural hearing loss (25\% error) and unilateral sensori-neural hearing loss (13\% error). However, in the former case there was only a small group of eight patients and thus these results are questionable. The trend indicates that the Weber is more efficient where cochlear reserve is not equal in both ears.

$\Lambda \mathrm{n}$ inherent limitation of the Weber is that it is not possible to interpret responses obtained when a mixed loss is present, or when there is a combination of sensori-neural loss in one ear and conductive loss in the other. The response obtained from the patient may thus prove misleading.

On considering the results for the Rinne, all results for similar cat egories i.e. normal, conductive, etc, were compared to assess whether results for any given category were comparable irrespective of the hearing characteristics of the contralateral ear. On analysis, results within each category did not differ significantly (all at $\mathrm{p}<0,05$ ) thus confirming test consistency.

The Rinne is generally efficient in depicting normal hearing and conductive losses. ( $\Lambda$ n arbitrary response was usually given with a conductive loss around $20 \mathrm{~dB}$, thus reducing efficiency in this region). Ears with a sensori-neural loss denonstrated a significant incidence of errors $(p<0,05)$ in only two combinations i.e. with a mixed loss $\left(35,70^{\circ}\right)$ and in the bilateral equal sensorineural group $(11,190)$. The latter is of borderline significance only. Sensorineural loss is therefore depicted less efficiently but results are still of value in diagnosis. Mixed losses give the least reliable results.

The use of masking to prevent the false-negative response in unilateral severe sensori-neural loss has long been a problem. The general difficulties in establishing effective masking levels are equally relevant here. The writer suggests that the false-negative response be accepted as it stands. In the present study, masking was not used. However, on analysis of results, the false-negative appears consistently where one would expect it to occur. The history, plus Weber and Schwabach tests, can be employed to provide further information (the present study found the Weber to be reliable in this category). There is, nevertheless, no totally satisfactory solution to this problem.

The greatest limitation of the Weber and Rinne tests is that inconsistencies may occur in any patient's responses for a variety of psycho-a coustic, ana- 
tomical and physical reasons. As with any test requiring a subjective response, these tests are only as efficient as the patients' prepared ness and ability to judge what is presented to him. Unsophisticated patients nay be more suggestible and erratic in this regard.

Although findings based on the audiometric Weber and Rinne cannot be directly compared to those obtained with tuning forks, owing to the slight differences in frequency levels and presentation, trends of test efficiency can be extracted.

Neither of these tests are sufficiently reliable to substitute for threshold tests. However, the findings of this study suggest that the Rinne is of value as a supplement to theshold testing. A result at variance with the threshold levels alerts the tester to the need for closer investigation. The Weber can be used reliably to help ident ify a unilateral sensori-neural loss but, clearly, its general inefficiency makes it of little diagnostic value.

\section{ACKNOWLEDGIIMENTS}

I wish to thank Dr B.L. Wolfowitz for his suggestions on presentation and Mrs J.E. Anderson for assisting with classification of results. Also, Mr (i.t. Kimble and the Department of Statistics, C.E.D., Johamesburg for the slatistical analysis; and Dr L. Faivelsohn, Medical Superintendent of Baragwanath Hospital for his permission to publish.

\section{REFERENCES}

1. Allen, G.W. and Fernandez, C. (1960): The Mechanism of Bone Conduction. Annals of Otol., Rhinol, and Laryngol., 69, 5-28.

2. Davis, H. and Silverman, S. (1970): Hearing and Deafness, 3rd edition Holt, Rinehart \& Winston, New York.

3. Groen, J.J. (1962): The Value of the Weber Test. In Schuknecht, H.F. (Ed.), Otosclerosis International Symposium, Chap. 14. Little, Brown \& Co., Massachusetts.

4. Harris, J.D., Haines, H.L. and Myers, C.K. (1953): A Helmet-held Bone Conduction Vibrator. Laryngoscope, 63, 998-1007.

5. Jesberg, S. (1923): Recording of Functional Hearing Tests. Laryngoscope, 33, 379-383.

6. Johnson, E.W. (1970): Tuning Forks to Audiometers and back again. Laryngoscope, 80, 49-68.

7. Naunton, R.F. (1963): The Measurement of learing by Bone Conduction. In Jerger; J. (Ed.), Modern Developments in Audiology, Chap. 1. Academic Press, New York.

8. Newby, H.A. (1965): Audiology Principles and Practice, 2nd edition. Vision Press, London.

9. Nilo, E.R. (1968): The Relation of Vibrator Surface Area and Static Application Force to the Vibrator-to-head Coupling. J. of Speech and Hearing Res., 11, 805.810. 
10. Shechy, J.L. et al. (1971): Tuning Fork Tests in Modern Otology. Arch. Otolarying., 94, 132-138.

11. Sonnenschein, R. (1933): Fundamental Principles of Functional Hearing Tests. Arch. Otolaryng., 18, 599-613.

12. Tschiassny, K. (1946): Tuning Fork Tests. Annals of Otol, Rhinol, and Laryugol, , 55, 423.430.

13. Watson, L.A. and Tolan, T. (1949): Hearing Tests and Hearing Instruments. Williams and Wilkins, Baltimore.

\title{
and \\ AUDIOMETRIC EQUIPMENT HEARING AIDS NOISE CONTROL
}

Maico

Interacoustics

Grason-Stadler

\author{
Siemens \\ - Madsen \\ Widex
}

Eckstein

Linco'

Willco

HILLARY REICHENBERG

ERIC C. LEWIS,

\section{THE NEEDLER WESTDENE HEARING AID ORGANISATION (PTY) LTD.}

P.O. BOX 28975, SANDRING HAM 2131

TELEPHONE : 45-7262 


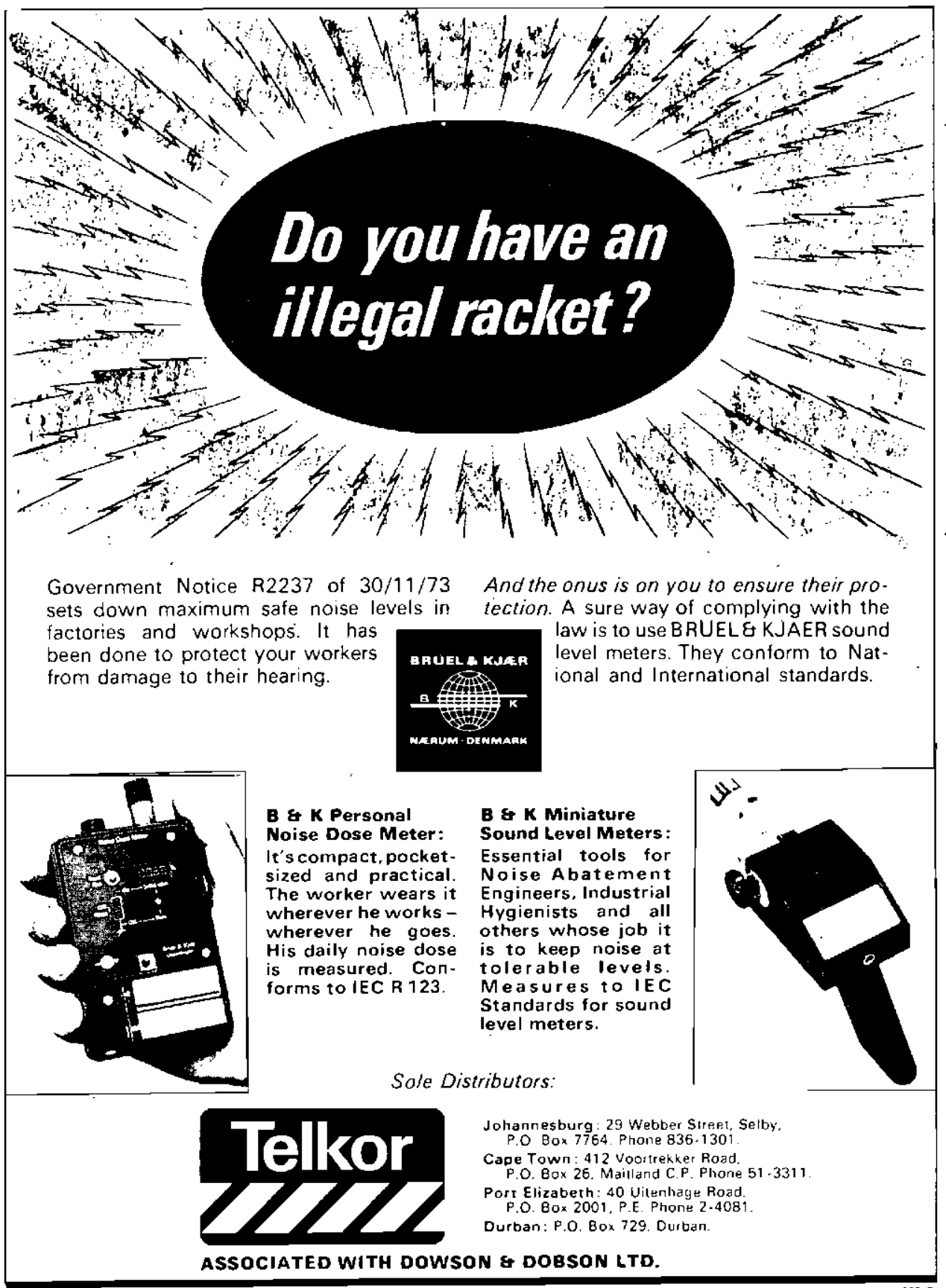

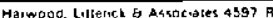




\section{AMPLIVOX HEARING SERVICES}

(PTY.) LTD.

SUITE $322-3$

BOSMAN BUILDING, COR. ELOFF \& BREE STREETS P.O. Box 9076 JOHANNESBURG Tel. 23-6419 23-6431

We are suppliers of the following:

HEARING AIDS

Amplivox, Dahlberg, Oticon, Rexton and Cosmocord Covering all types of hearing aids.

\section{AUDIOMETERS}

Amplivox, Amplaid, Peters and Tracor Manual and Automatic Audiometers of all types.

ACOUSTIC BOOTHS AND SOUND LEVEL METERS

Tracor, Amplivox and Acos.

DEAF SCHOOL EQUIPMENT

Peters, Connevans and Amplivox Speech Training and Group Hearing Aids.

\section{EAR DEFENDERS}

Gunfender, Sonex, Super Sonex, Interceptor, Auralgard, Sonogard and Supamuff from Amplivox.

\section{AMPLIVOX HEARING SERVICES}

The Acknowledged Experts 


\section{Aids for}

- the development of perception

- the acquisition of speech and language skills

- the improvement of motor co-ordination

Plus

- helpful texts for therapists

- educational toys, books and equipment

- records for auditory training

- catalogues on request

- Large variety of tests recently arrived

\section{Consult}

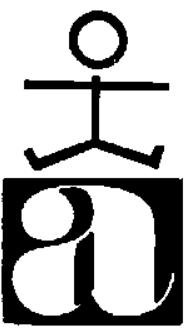

PLAY AND SCHOOLROOM

8 Tyrwhitt Avenue, Rosebank

(adjoining the Constantia Cinema)

Telephones: 42-5350; 42-6529.

P.O. Box 52137, Saxonwold, Tvl. 